\title{
Graduate curriculum: A need for a change
}

\author{
Dilyana D.Sungatullina ${ }^{1}$, Ekaterina O.Murtazina ${ }^{1}$ and Yuliya N.Gorelova ${ }^{1 \mathrm{a}}$ \\ ${ }^{1}$ Kazan Federal University, 420008, 18, Kremlevskaya str., Russia
}

\begin{abstract}
Over the last couple of years there was an increase in graduates' willingness to interleave their vocational careers with academic instruction at the university. Hence, the authors conducted evaluation and needs analysis of the skills crucial for graduate students to possess. The current study analyzed the attitude of $150 \mathrm{KFU}$ IMEF graduates towards their core requirements within the framework of modern educational environment. The results showed that the majority of the respondents consider knowledge of teaching methodology (a new topic introduction, the material delivery, its further practice and revision, effective groupwork and public speaking) to be of great importance. The paper concludes with suggestions on the need for the development and the introduction of a cutting-edge course at a Master's level tailored to graduates to enhance the skills applicable not only in the professional field but the educational environment as well.
\end{abstract}

Keywords: modern educational environment, attitude, graduate students

\section{Introduction}

Education in the 21 st century is undergoing significant changes due to profound modifications in the requirements to the University graduates set by business and industrial landscape. New educational paradigm determines the competences and skills which stakeholders, namely potential employers, consider essential for the graduates employability [1].

The current trend observed is that employers pay significant attention to the soft or transferable skills development, while the University still focuses on training the hard ones. Most employers believe that there is a competence gap between skills necessary for the successful employment in the company and the skills acquired by the graduates in the universities [2]. Unlike hard skills, which determine the person's ability to perform specific tasks, soft skills are more universal and applicable in almost all jobs. The European Union and OECD countries have done a considerable amount of work to define the "21st century skills" inducing many schools to review the stand-and-deliver model of teaching and learning, introduce technology in the education process, reshape pedagogy to answer new shift. Even though the curriculum design presupposes the inclusion of transferable skills

\footnotetext{
${ }^{\text {a }}$ Corresponding author: gorelovajuliya@gmail.com
} 
development in the teaching process, the challenge is that they are difficult to test and control, therefore the practice shows that hard skills are still a priority for tertiary institutions. Thus, we may observe a contradiction that made the authors consider the problem of curriculum development and address the changes that it needs to undergo in order to meet the requirements of contemporary world.

Any university is an employer itself as a certain percentage of graduates holding master's degree, stays at the University as a tertiary teacher. Thus, the University experiences the same problem as other employers do - the lack of soft skills among graduates, who made their decision to go on with teaching career on a full-time or part-time basis [3]. Therefore, the problem doubles due to the fact that novice tertiary teachers are incompetent of building soft skills in other students. Traditional solution offered by Russian higher education system is the professional development programs (PDP) or advanced training courses, which are obligatory to be taken by novice tertiary teachers along with their more experienced colleagues every three years. Notwithstanding the fact that academics are free to choose the field and the mode of PDP, quite frequently the programs, sponsored by the state, are far from being efficient and do not satisfy the requirements set by the University.

All the assumptions mentioned above induced the authors to consider the stated problem at Kazan Federal University, namely the Institute of Management, Economics and Finance (IMEF KFU). Therefore, the goal of this research is to identify the skills that would fill the current gap in the curriculum to provide relevant and competitive qualification for the graduates.

\section{Research questions}

To achieve the goal of our research, we will address two questions:

1. What soft skills are essential for a university graduate applicable not only in the professional field but in educational environment as well?

2. How could the curriculum be altered to meet the requirements of soft skills development?

\section{Theoretical background}

\subsection{Overseas soft skills development approaches}

The relevance of soft skills development is indisputable and highlighted by all stakeholders. The review of employers' preferences has revealed that transferrable skills that are considered as a "must have" for a graduate include reliability, interpersonal skills (teamworking), problem-solving (accountability) communication, self-direction and creativity (innovation) [4].

As both universities and businesses acknowledge significance of the issue for the Russian community the authors analyzed the existing international and domestic approaches to soft skills development. The analysis revealed that HEIs basically implement the following measures:

1.Publish students' guidelines on the university official website recommending to pay enough attention to soft skills development (to take a professional course, to volunteer in the community, to participate in class or to teach a class, to become a mentor or to get involved in the students' organizations.) 
2. Introduce zero-credit courses, where students have an opportunity of practicing their social skills.

3. Introduce mandatory soft skills course in the curriculum with particular attention paid to interpersonal, communication and leadership skills development (bolt on model) [5].

4. Develop soft skills within the campus surrounding.

5. Organize work-integrated learning or internships together with potential employers.

6. Include soft skills development component in the hard skills course syllabus (imbedded model) [6].

The international experience observed advocates the implementation of the imbedded model i.e. the inclusion of soft skills into teaching hard ones. This approach possesses an indispensable benefit - there is no need to introduce a new course into the already overloaded curriculum. However, this requires a complete revision of teaching methodology and teachers' attitude to the course delivery [7].

\subsection{Home experience}

Domestic tertiary education is built around federal state educational standards (namely FSES 3+), which implies the competence approach implementation while designing the course syllabus. The standard presupposes the division of all competences into professional (similar to hard skills), general cultural and general professional ones which have a wide application field and indirectly relate to soft skills development. Thus, we may conclude that Russian tertiary education system utilizes the imbedded model as well. However, the standard does not describe the tools for measuring the degree of competence development among graduates and, in fact, these general cultural and general professional competences are difficult to measure and assess inside the professional course syllabus. Moreover, most teachers in their 40s-60s lack the required soft skills and are ignorant of their importance. Therefore, we may conclude that the problem of soft skills development in Russian universities in general and in IMEF KFU in particular is acute, as the existing system does not bring the desired effect. It requires serious consideration from the point of the university management, course designers and policy makers.

The authors have analyzed the IMEF KFU current graduate curriculum designed according to the FSES $3+$ and identified the general cultural / general professional competences or soft skills that are to be developed in the course of programs mastering [9].

The general cultural competences prioritize analytical thinking, adaptability, social responsibility; general professional competences include communication skills (oral and written in native and foreign languages), leadership skills, cultural awareness and tolerance. The main advantage of the graduate curriculum in IMEF KFU is that along with compulsory vocational subjects preparing students for their future qualifications, there is a range of soft skills developing courses, which are predominantly elective. However, the variety of such courses is rather low and in many cases they are not represented in all majors of Master degree programs. The top 5 most popular programs in economics, management and environmental engineering do not have elective courses on soft skills development, while state and municipal management program along with human resources management allow incorporate $5 \%$ of optional subjects which are free to be chosen by students.

Thus, the authors of current research assume that a new course introduction to the curriculum of graduate students of all majors within IMEF KFU is of an utmost importance. Furthermore, this course should provide students with soft skills applicable not only at a tertiary education level (in case they decide to merge their career in business with teaching prospects) but be transferrable in all the spheres of their professional development. 


\section{Research methodology}

To identify the necessity of a new curriculum design for Master Students the authors subdivided the research into four stages.

Stage 1.

The primary objective of this stage in research was the quantitative analysis of the IMEF KFU graduates who preferred to continue their career path as a tertiary-level teacher within 2010 to 2016 timeslots out of 500 academic staff of the Institute.

Stage 2.

This stage was concerned with the calculation of costs that IMEF KFU spends annually from the Federal budget of the Russian Federation on PDP of its academic staff. At this stage we estimated the potential savings that the University can obtain by introducing the teaching methodology course into the Master's curriculum.

Stage 3.

In the third stage we collected the information on the skills, which are critical for students to burnish in case they wish to blend their vocational careers with teaching at the university. Our data are based on responses of the 162 IMEF KFU 22-24 year-old Master students who completed the online questionnaire. The research questions outline the issues concerning students' work experience, willingness/unwillingness to interleave their major qualification and option of teaching at a tertiary level; crucial skills to be obtained before embarking on the career in education, including teaching methodology, teamwork organization, interaction with the audience; desire to hold lectures and seminars in English for the international audience.

Stage 4.

At the final point of our research we used binary variables in various dimensions (high versus low): employment status/desire to teach at HEI, employment status/desire to enroll in the teaching methodology course, desire to teach at HEI/ students' assessment of teaching methodology relevance, desire to enroll in the teaching methodology course/desire to teach at HEI. The degree of correlation between the variables was calculated with Pearson correlation coefficient.

\section{Results and discussion}

At the first stage of our research we have identified that $11.6 \%$ of the tertiary teachers educating at IMEF KFU are novice teachers graduated from the Institute in the period of 2010-2016 (58 out of 500 faculty members). Thus, we could conclude that annually approximately 3 graduates stay at IMEF KFU to teach. Therefore, the issue of the graduates skills and qualifications is of an utmost importance.

In accordance with the expenditures from the federal budget of the Russian Federation in 2016 education accounts for 9.18\% [10]. However, expenses on professional development programs and further vocational training programs constitute only $1.29 \%$ from total investments into the sphere of education. Thus, we have calculated that the introduction of the teaching methodology course into the Master students' curriculum of IMEF KFU may save $0.16 \%$ from the total amount of spendings to the PDP from the federal budget of the Russian Federation. Consequently, former graduates may attend any other PDP, which will be crucial for them at the start of their teaching career. 
Having compared the soft skills requirements of potential employers, with the existing competences to be developed in the curriculum, the authors have identified the gap. To fill this gap we have explored the existing needs of current students about the skills and competences, which they consider vital to develop. According to the data provided in Figure 01 , the majority of the respondents $(87.6 \%)$ indicate that being aware of teaching methodology for academics at a tertiary level is of great relevance. What is more, Figure 02 illustrates that a significant number of graduates $(61.4 \%)$ feel indispensability of a teaching methodology course implementation into their current curriculum.

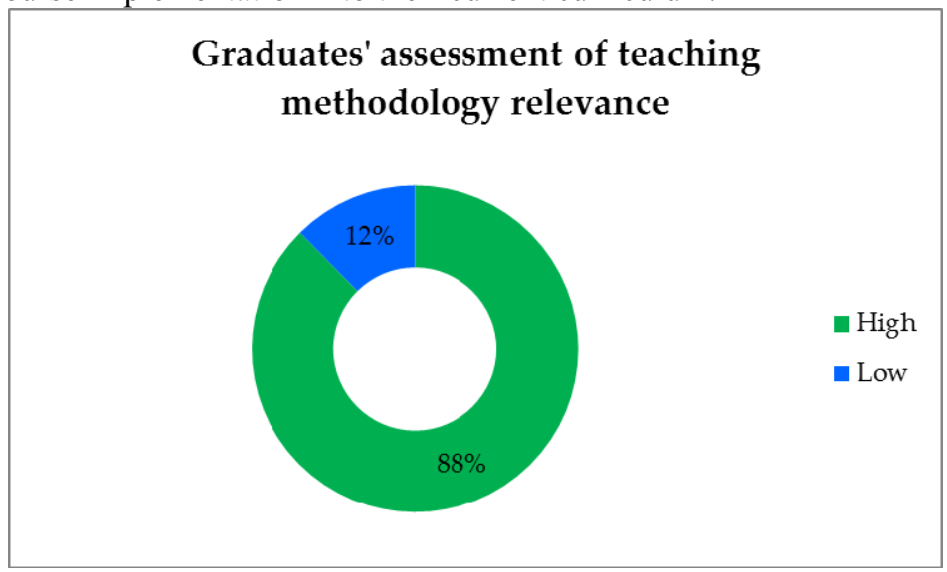

Fig. 01 [The importance of teaching methodology awareness as a tertiary teacher]

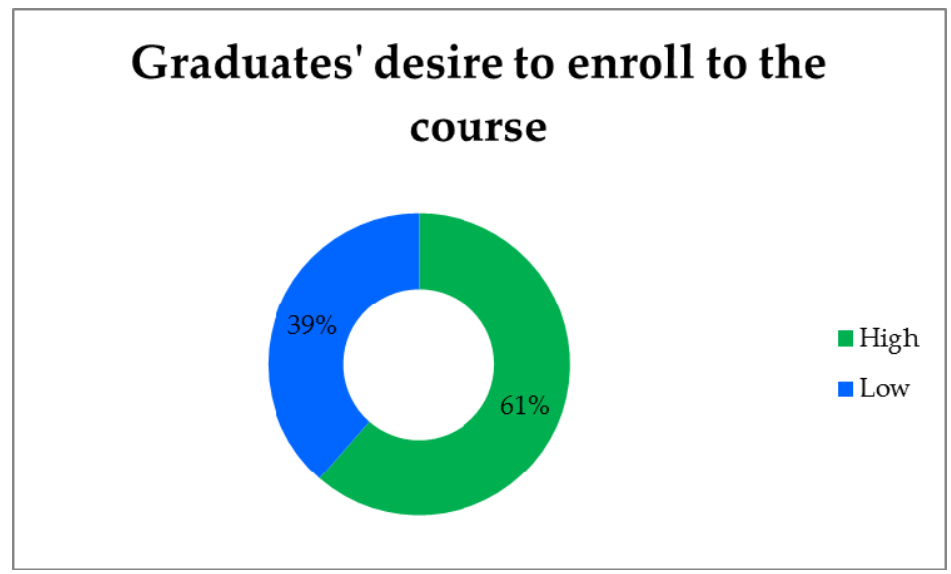

Fig. 02 [Teaching methodology course necessity within Master's curriculum]

The data collected from Figure 03 emphasize the most crucial and desirable skills for the graduates to obtain if the course described is taken into account when designing a curriculum. It is interesting to notice, that more than $58 \%$ of the respondents consider classroom management skills such as topic introduction or material delivery to be the most significant ones. Public speaking (51.7\%), interactive teaching methods $(50 \%)$ and ability to attract an audience attention (48.3\%) seem quite meaningful to the participants of the survey as well. Besides, such skills as interaction with the audience $(30 \%)$, knowledge assessment (13.3\%), structuring presentations (11.7\%) are of less valuable. 


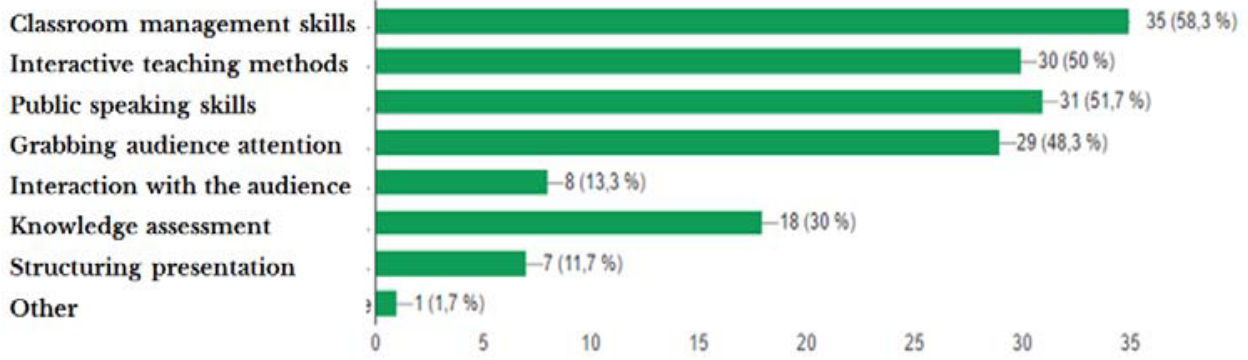

Fig. 03 [Targeted skills to be learnt within teaching methodology course]

Figure 04 demonstrates graduates' willingness and unwillingness to interleave their major qualification and option of teaching at a tertiary level. A relatively large number of respondents $(43.4 \%)$ would wish to stay at the university for teaching practice and experience.

\section{Graduates' desire to teach at HEI}

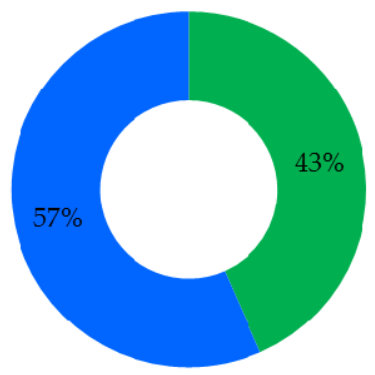

migh

$\square$ Low

Fig. 04 [Graduates' desire to teach at a tertiary level]

Therefore, the results show that the majority of the respondents consider knowledge of teaching methodology to be of the highest priority, thus, confirming their wish to enroll in the course. The participants of the research demonstrate an encouragement towards learning the ways of effective groupwork organization, as well as new topic introduction, material delivery, its further practice and revision. Along with these, public speaking skills and interactive teaching methods are also in high demand.

The final step of our research revealed the correlation between employment status/desire to teach at HEI, employment status/desire to enroll in the teaching methodology course, desire to teach at HEI/ students' assessment of teaching methodology relevance, desire to enroll in the teaching methodology course/desire to teach at HEI (Table 1). As we can observe from the Table 1, there are no or very low cause-effect relations between the variables represented in the first 3 dimensions. However, the last variables correlation, namely "Graduates' desire to enroll in teaching methodology course / Graduates' desire to teach at HEI", is characterised by a negative trend, signifying the fact that the more students want to teach at HEI - the less they find a necessity of attending teaching methodology course. Nevertheless, the results of our previous research prove that teachers, as a rule, face the issues, which can be basically solved through a teaching methodology course [8]. Thus, the primary objective of a new course is to break the 
traditional viewpoint to the teaching methodology, transforming it into the vital soft skills development platform applicable in the educational and business landscape.

Table 1. Indicators affecting Graduates' desire to teach

\begin{tabular}{|c|c|}
\hline Variables Correlation & Correlation Coefficient \\
\hline Employment status / Graduates' desire to teach at HEI & $0,26^{*}$ \\
\hline $\begin{array}{c}\text { Employment status / Graduates' desire to enroll in teaching } \\
\text { methodology course }\end{array}$ & $-0,06^{*}$ \\
\hline $\begin{array}{c}\text { Graduates' desire to teach at HEI/Relevance of teaching } \\
\text { methodology }\end{array}$ & $-0,016^{*}$ \\
\hline $\begin{array}{c}\text { Graduates' desire to enroll to teaching methodology course / } \\
\text { Graduates' desire to teach at HEI }\end{array}$ & $-0,61^{*}$ \\
\hline
\end{tabular}

$\left({ }^{*} \mathrm{p} \leq 0,05\right)$

\section{Conclusion}

Thus, in the course of our research we have identified that there is a significant gap between the skills and qualifications taught at the universities and the requirements of the labour market. The University as an employer itself is attempting to solve the problem by obligatory advanced training courses for its faculty members, which however provide doubtful effect. Therefore, the authors come up with suggestions on the urgency for the designing of an advanced course at a Master's level, which will positively impact the professional sphere and academic environment as well. Needs analysis performed, exposed that students focus on diverse labour market sectors requiring a combination of skills. However, the data obtained in the course of the research signify the fact that the education sector gains its strength and prestige demonstrating favourable ambiance for entry-level candidates to start their careers. Furthermore, new course design can diminish the governmental expenditures on tertiary teachers professional training due to the fact that the course offered can potentially be regarded as a base for the set of competencies development indispensable for the academics at a tertiary level.

\section{References}

1. E. M. Galishnikova, T. A. Baklashova, L. V. Khafizova, Formation of Student's Tolerance in Multicultural Environment When Teaching a Foreign Language (KFU Experience, Kazan, Republic of Tatarstan, Russia). European Proceedings of Social and Behavioural Sciences, 12, 38-44, (2016)

2. L. R. Ismagilova, O. V. Polyakova, The problem of the syllabus design within the competence approach based on the course "English for Master Degree Students in Economics (advanced level)". Procedia Social and Behavioral Sciences, 152,1095$1100,(2014)$

3. I. M. Solodkova, L. R. Ismagilova, Acquisition of Socio-Cultural Competence via Dynamic Learning Environment. European Proceedings of Social and Behavioural Sciences, 12, 389-395, (2016) 
4. L. Rider, Soft skills starter kit ...\& guide. Retrieved from http://wastatecouncil.shrm.org/sites/wastatecouncil.shrm.org/files/Soft $\% 20 \mathrm{Skill} \% 20 \mathrm{Su}$ rvey\%20Rpt\%20-\%20Sum\%20of\%20Findings\%20-\%20031615.pdf. (March, 2016).

5. S. Roselina Soft skills at Malaysian institute of higher learning. Asia Pacific Education Review, 10, 309-315, (2009)

6. E. Dunne, Personal transferable skills: Final report. Exeter: University of Exeter, (1995)

7. B. Schulz, The Importance of Soft Skills: Education beyond academic knowledge. NAWA Journal of Language and Communication, 146-154, (June 2008).

8. Sungatullina D. D., Zalyaeva E. O., Gorelova Y. N. Time for a change: defining the academic teacher's brand pillars. III International Forum on Teacher Education, Kazan, (to be published), (2017)

9. Federal'nyye gosudarstvennyye obrazovatel'nyye standarty 3+ Magistratura (Federal state educational standards 3+ Master's level) (n.d.). Retrieved from http://cfuv.ru/federalnye-gosudarstvennye-obrazovatelnye-standarty-3-magistratura (Last update: 2017, April, 26)

10. Raskhody konsolidirovannogo byudzheta Rossiyskoy Federatsii po razdelu «Obrazovaniye» v 2016 godu (Consolidated budget expenditures on Education in Russia in 2016). Retrieved from http://fin.edu.ru/InfoPanel/min_obr1.html (Last update: 2017, April, 26). 